\title{
Economic Feasibility Study on PV/Wind Hybrid Microgrids for Indonesia Remote Island Application
}

\author{
Syafii Syafii ${ }^{1}$, Pinto Anugrah ${ }^{1}$, Heru Dibyo Laksono ${ }^{1}$, Herris Yamashika ${ }^{2}$ \\ ${ }^{1}$ Electrical Engineering Department, Faculty of Engineering, Universitas Andalas, Padang, Indonesia \\ ${ }^{2}$ Electrical Engineering Department, Universitas Muhammadiyah Sumatera Barat, Bukit Tinggi, Indonesia
}

\begin{abstract}
This paper presents the economic feasibility of hybrid microgrid power system for three remote islands of Sumatra, Indonesia. The microgrid system simulated and analysed using Homer Pro software. Optimization results showed that the combination of photovoltaic (PV), diesel generation (G) and batteries (Batt) for microgrid power system in Mandeh and Lagundri Island area were the most economical configuration. Meanwhile, for Mentawai area, the combination of PV, Wind Turbine (WT), G, Batt was the most optimal since it has higher wind speed then the other two areas. The Mandeh area has the highest solar radiation compared to the other two areas, resulting in the lowest $\mathrm{CoE}$ of $\$ 0.096 / \mathrm{kWh}$ as well as the lowest investment and operational costs. For the fixed PV $100 \mathrm{~kW}$ scenario, the optimal configuration is obtained with $86 \mathrm{~kW}$ supplied by WT for the Lagundri location, and $67 \mathrm{~kW}$ supplied by WT for the Mentawai area, while the WT installation area is not recommended for Mandeh location. The power management analysis showed that the average and patterns of weather parameters including solar radiation and wind speed effect both $P V$ and Wind electrical power production.
\end{abstract}

Keywords - economic feasibility, hybrid microgrid system, PV/Wind and Indonesia remote application.

DOI: 10.18421/TEM104-66

https://doi.org/10.18421/TEM104-66

Corresponding author: Syafii Syafii,

Electrical Engineering Department, Faculty of Engineering, Universitas Andalas, Padang, Indonesia

Email: syafii@eng.unand.ac.id

Received: 16 May 2021.

Revised: 18 October 2021.

Accepted: 25 October 2021.

Published: 26 November 2021.

(c) BY-NC-ND (C) 2021 Syafii Syafii et al; published by UIKTEN. This work is licensed under the Creative Commons Attribution-NonCommercial-NoDerivs 4.0 License.

The article is published with Open Access at www.temjournal.com

\section{Introduction}

The electricity supply to remote islands can improve the socio-economic status of the community. Today, many researches focused on renewable energy technologies because they play important role in improving the quality of life by fulfilment of electricity needs and being environmentally friendly [1], [2]. Among these renewable energy technologies, the generation of electrical energy from primary energy sources such as sunlight and wind is an option that is currently being developed and will be widely used in the future [3], [4]. Both resources are abundant and do not produce greenhouse gas emission [5], [6]. The integration of renewable energy into existing energy grids not only reduces dependence on fossil fuels but also provides sustainable solutions for future power generation [7].

Indonesia as one of the developing countries where the power plant is still dominated by fossil energybased generators is trying to increase the use of energy from renewable sources. Through the National Energy Policy (NEP), Indonesia has targeted the use of new and renewable energy by $23 \%$ in 2025 and $31 \%$ in 2050 [8]. According to the Indonesia Energy Outlook 2016, there is about 135.5 GW installed capacity required in 2025, and 45.2 GW will be coming from renewables [9]. Therefore, research that analysed the use of renewable energy in various regions in Indonesia is urgent to be done.

Indonesia is an archipelago country and is crossed by the equator [10], has natural beauty and abundance of solar [11] and small wind speed energy potential [12]. The beauty of Lagundri beach in the Nias archipelago, Mandeh island resort and beaches in the Mentawai islands are the main attractions for both foreign tourists and domestic tourists. The islands of Nias, Mentawai and Mandeh are priorities for the development of electricity access because of the potential for beautiful tourism sites. Therefore, these three areas were taken in this study as a case study location for the development of a hybrid 
microgrid for coastal areas. These islands coastal area were chosen, because the electricity network from the state electricity company of Indonesia (PLN) is not yet reached.

\section{Materials and Methods}

The present study focuses on the optimal configuration and energy production analysis of renewable hybrid energy system for electrification of the coastal community located on the Sumatra coastal area, Indonesia. The proposed hybrid microgrids are a study for three different locations in Sumatera coastal area as shown in Fig. 1. for Lagundri, Mandeh and Mentawai coastal area. These locations have potential natural resources and are enriched with wind and solar availability.

HOMER software is used for microgrid system design and simulation. This software is widely used to study the technical and economic feasibility of developing renewable energy plants to date [13], [14]. This software can also be used to determine the most optimal generator configuration as well as to see the flow of generation power in serving the load of a microgrid system [15], [16]. The HOMER software was used to design and optimize the hybrid microgrid system with the diesel system presented as the base case. Several data need to be prepared before carrying out HOMER simulations including load demand data, weather condition data and technical and economic data from each system components.

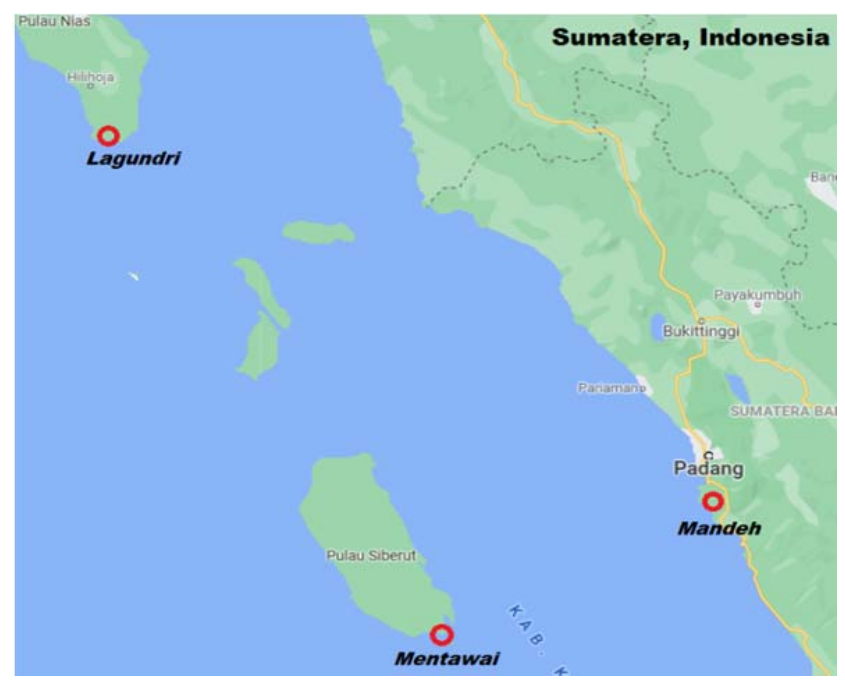

Figure 1. Geographical position of three coastal areas in Sumatera, Indonesia under study

\subsection{Load profile of Mentawai Island Microgrid}

The electricity load of remote island case study consists of two kinds of electrical demand: household and commercial/public demand. The household minimum load is $180 \mathrm{~W}$ to cover refrigerator, warm rice cooker and small item and maximum load is $90 \%$ of $900 \mathrm{VA}=810 \mathrm{~W}$. Sixty households were used in this study with average load of $16.73 \mathrm{~kW}$, and a peak load of $50,36 \mathrm{~kW}$. The load factor is equal to the average load divided by the peak load. Therefore, the load factor is $16.73 \mathrm{~kW} / 50,36 \mathrm{~kW}=0.33$. Based on the usage pattern, the average load energy consumption is $401.40 \mathrm{kWh} /$ day. Whereas the commercial/public demand consumed $33.68 \mathrm{kWh} /$ day as tabulated in Table 1.

Table 1. Community load profile

\begin{tabular}{|c|c|c|c|c|}
\hline Type & $\begin{array}{c}\text { Load } \\
(\mathrm{W})\end{array}$ & Qtity & $\begin{array}{c}\text { Op.Time } \\
\text { (hour) }\end{array}$ & $\begin{array}{c}\text { kWh } \\
\text { Consp }\end{array}$ \\
\hline Household & 810 & 60 & 8.26 & 401.4 \\
\hline \multicolumn{4}{|c|}{$\begin{array}{c}\text { Total Residential (60 household) } \\
\text { Demand (Load I) }\end{array}$} & 401.4 \\
\hline $\begin{array}{c}\text { Small } \\
\text { Business } \\
\text { load }\end{array}$ & 400 & 2 & 12 & 9.6 \\
\hline Street light & 30 & 4 & 9 & 1.08 \\
\hline School & 1500 & 1 & 10 & 15 \\
\hline $\begin{array}{l}\text { Community } \\
\text { office }\end{array}$ & 1000 & 1 & 8 & 8 \\
\hline \multicolumn{4}{|c|}{$\begin{array}{c}\text { Total Commercial/Public Demand } \\
\text { (Load II) }\end{array}$} & 33.68 \\
\hline
\end{tabular}

\subsection{Solar and Wind Resources}

The weather data of solar radiation and average wind speed of the three coastal areas are shown in Table 2. and 3. The average annual solar radiation value is $4.73 \mathrm{kWh} / \mathrm{m}^{2} /$ day, $4.8 \mathrm{kWh} / \mathrm{m}^{2} /$ day and 5.23 $\mathrm{kWh} / \mathrm{m}^{2} /$ day for Lagundri, Metawai and Mandeh area respectively. The maximum average solar radiation recorded in February and April is 5.54 $\mathrm{kWh} / \mathrm{m}^{2} /$ day for Mandeh area while the minimum average solar radiation is recorded in November, which is $4.26 \mathrm{kWh} / \mathrm{m}^{2} /$ day for Lagundri area.

Table 2. Average radiation in $\mathrm{kWh} / \mathrm{m}^{2} /$ day

\begin{tabular}{|c|c|c|c|}
\hline \multirow{2}{*}{ Month } & \multicolumn{3}{|c|}{ Average Radiation (kWh/m²/day) } \\
\hline & Lagundri & Mentawai & Mandeh \\
\hline Jan & 4.90 & 4.77 & 5.22 \\
\hline Feb & 5.25 & 5.21 & 5.54 \\
\hline Mar & 4.97 & 5.10 & 5.48 \\
\hline Apr & 4.78 & 4.97 & 5.54 \\
\hline May & 4.98 & 4.97 & 5.34 \\
\hline Jun & 4.87 & 4.82 & 5.28 \\
\hline Jul & 4.56 & 4.69 & 5.12 \\
\hline Aug & 4.54 & 4.75 & 5.09 \\
\hline Sep & 4.51 & 4.77 & 5.28 \\
\hline Oct & 4.51 & 4.69 & 5.11 \\
\hline Nov & 4.26 & 4.36 & 4.78 \\
\hline Dec & 4.57 & 4.54 & 4.96 \\
\hline Average & 4.73 & 4.8 & 5.23 \\
\hline
\end{tabular}


The average annual wind speed value is $3.51 \mathrm{~m} / \mathrm{s}$, $3.82 \mathrm{~m} / \mathrm{s}$ and $2.89 \mathrm{~m} / \mathrm{s}$ for Lagundri, Metawai and Mandeh area respectively. The maximum average wind speed recorded in September is $4.42 \mathrm{~m} / \mathrm{s}$ of Mentawai area while the minimum average wind speed is recorded in November, which is $2.60 \mathrm{~m} / \mathrm{s}$ for Mandeh area. Based on both weather data, it shows that Mandeh area has the highest solar radiation, whereas the Mentawai area has the largest wind speed.

Table 3. Average wind speed in $\mathrm{m} / \mathrm{s}$

\begin{tabular}{l|c|c|c}
\hline \multirow{2}{*}{ Month } & \multicolumn{3}{|c}{ Average Wind Speed (m/s) } \\
\cline { 2 - 4 } & Lagundri & Mentawai & Mandeh \\
\hline Jan & 3.31 & 3.86 & 2.76 \\
\hline Feb & 3.30 & 3.80 & 2.79 \\
\hline Mar & 3.50 & 3.71 & 2.89 \\
\hline Apr & 3.30 & 3.34 & 2.73 \\
\hline May & 3.06 & 3.13 & 2.60 \\
\hline Jun & 3.27 & 3.39 & 2.65 \\
\hline Jul & 3.53 & 3.66 & 2.80 \\
\hline Aug & 3.54 & 4.33 & 3.12 \\
\hline Sep & 3.71 & 4.42 & 3.10 \\
\hline Oct & 3.98 & 4.10 & 3.10 \\
\hline Nov & 4.09 & 4.08 & 3.16 \\
\hline Dec & 3.52 & 4.05 & 3.00 \\
\hline Average & $\mathbf{3 . 5 1}$ & $\mathbf{3 . 8 2}$ & $\mathbf{2 . 8 9}$ \\
\hline
\end{tabular}

These two weather parameters are used as input for Homer's software for analysing the economic feasibility of $\mathrm{PV} /$ wind powered microgrid system. The wind speed and solar radiation profiles are close to the weather patterns in various remote islands in Indonesia. Therefore, the results of this study can become a consideration for the development of $\mathrm{PV} /$ Wind hybrid microgrid for Indonesia remote island application.

\subsection{System Configuration}

The proposed coastal microgrid system comprises of five components, mainly diesel generator, PV system, wind turbine, AC-DC converter, and battery bank as shown in Fig. 2. All of these components are connected through AC or DC bus. Two type of load demand are connected to AC bus for residential load and commercial/public load.

The specifications of remote island microgrid system components are provided in Table 4. The current fuel price adjustment is based on the implementation of the Ministerial Decree of ESDM No. $62 \mathrm{~K} / 12 / \mathrm{MEM} / 2020$ concerning basic price formula in calculation of retail sales prices for general fuel oil types of gasoline and diesel oil distributed through public fuel filling stations or fishermen filling stations. The price of diesel genset fuel cost is $\$ 0.68$ per litre. The economic parameter inputs of the project for inflation target and the nominal discount rate are $3 \%$ and $4.5 \%$, respectively.

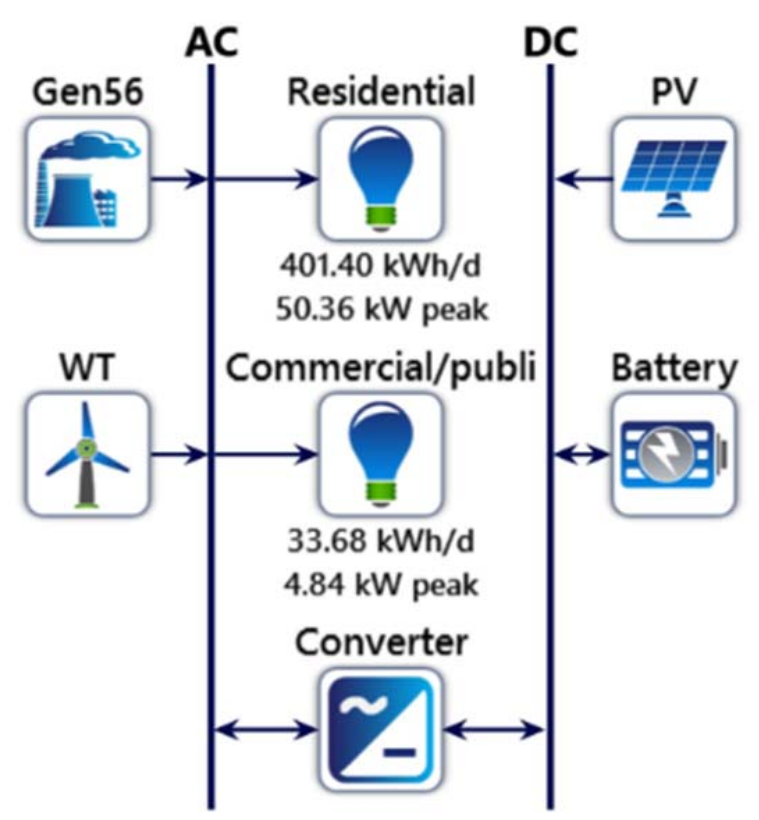

Figure 2. Proposed microgrid system components

Table 4. Microgrid power system components cost

\begin{tabular}{l|c|c|c|c}
\hline Component & $\begin{array}{c}\text { Capital } \\
\mathbf{( \$ / k W )}\end{array}$ & $\begin{array}{c}\text { Replacement } \\
\mathbf{( \$ / k W )}\end{array}$ & $\begin{array}{c}\text { O\&M } \\
\mathbf{C o s t}\end{array}$ & $\begin{array}{c}\text { Life } \\
\text { time } \\
(\mathbf{y r})\end{array}$ \\
\hline PV System & 643 & 0 & $5 \$ / \mathbf{y r}$ & 25 \\
\hline WT Gen & 750 & 250 & $10 \$ /$ yr & 20 \\
\hline Genset & 500 & 450 & $\begin{array}{c}0.03 \\
\$ / O p . h r\end{array}$ & 15 \\
\hline Battery & 215 & 215 & 0 & 12.5 \\
\hline Inverter & 150 & 150 & 0 & 15 \\
\hline
\end{tabular}

The output of the simulation results is in the form of an optimal system design model to be analysed. By considering economic parameters: net present cost (NPC), cost of energy (COE), the optimal hybrid microgrid power system configurations (PV/WT/D/Battery) for the remote island area are determined. The NPC is calculated using the following expression:

$$
\mathrm{NPC}=\mathrm{CC}+\mathrm{RC}+\mathrm{O} \& \mathrm{M} \text { Cost }+\mathrm{FC}-\text { Salvage }
$$

where:

$\mathrm{NPC}=$ Net Present Cost (IDR)

$\mathrm{CC}=$ Capital Cost (IDR)

$\mathrm{RC}=$ Replacement Cost (IDR)

O\&M Cost $=$ Operation and maintenance cost (IDR)

COE is the average value of electrical energy per $\mathrm{kWh}$ produced by the system in a project. The COE has criteria if it is less than the basic cost of providing electricity, then it is feasible to continue, if it is greater than it is not feasible to continue. The calculation of the COE value can be done using the following equation:

where:

$$
\mathrm{CoE}=\mathrm{TAC} / \mathrm{kWh}_{\text {Tot_Prod }}
$$


TAC $=$ Total Annualized Cost (IDR) $\mathrm{kWh}_{\text {Tot_Prod }}=$ Total $\mathrm{kWh}$ production $(\mathrm{kWh})$

\section{Result and Discussion}

Technical and economic feasibility simulation conducted through the HOMER base optimalization and PV fixed optimalization by varying project location. In the first scenario, the HOMER search space automatically to optimize system fulfilling the electricity load. The second scenario uses fixed capacity of $100 \mathrm{~kW} \mathrm{PV} \mathrm{system,} \mathrm{while} \mathrm{the} \mathrm{other}$ components search space automatically to optimize system fulfilling the electricity load.

\subsection{Optimal Configuration}

In the simulation process, HOMER estimates the cost and at the same time determines the feasibility of hybridized systems over the year with a list of system configurations and their capacities are sorted based on the lowest $\mathrm{CoE}$ and NPC. The simulation results of the optimal microgrid system configuration for the study site in Lagundri, Nias Islands are shown in Table 5 .

Table 5. Optimal results based on HOMER optimization for all components

\begin{tabular}{l|c|c|c|c|c}
\hline \multicolumn{1}{c|}{ Config } & PV (kW) & WT (kW) & Genset (kW) & Battery (unit) & Inverter (kW) \\
\hline PV/G/Batt & 169 & & 56 & 416 & 51,3 \\
\hline PV/WT/G/Batt & 170 & 1 & 56 & 416 & 53,0 \\
\hline PV/Batt & 242 & & & 488 & 55,6 \\
\hline PV/WT/Batt & 349 & 1 & & 340 & 49,1 \\
\hline WT/G/Batt & & 552 & 56 & 384 & 117,1 \\
\hline PV/G & 331 & & 56 & & 37,8 \\
\hline PV/WT/G & 328 & 2 & 56 & & 42,3 \\
\hline G/Batt & & & 56 & 12 & 12,7 \\
\hline WT/G & & 5 & 56 & & \\
\hline G & & & 56 & & \\
\hline
\end{tabular}

Based on Table 5., PV installation is more profitable than WT and diesel generator, but if PV is not available then WT is better than diesel generation + limited PV combination. Therefore, PV is priority while WT is more competitive than Genset.

The economic comparison results for of optimal configuration of proposed Lagundri microgrid system is shown in Table 6. The optimal configuration has $\$ 0.104$ per $\mathrm{kWh}$ cost of energy and lowest NPC of $\$ 342,372.80$. Although the PV/G/Batt configuration requires a large initial capital of $\$ 234,085.50$, the operating costs are small at $\$ 5,198.85$. The PV system has no operating cost, it is available in nature, thus the largest portion of $98.07 \%$ renewable fraction is $\mathrm{PV} / \mathrm{G} /$ Batt configuration as shown in Table 6.

The proper power management is required to achieve reliability of the hybrid microgrid system. In

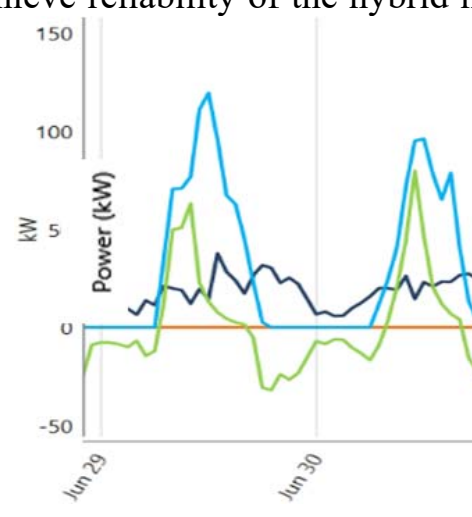

this system, diesel generator is operated on least priority, when PV, WT and batteries are unable to meet the residential and public load demand.

Table 6. Optimal result based on HOMER optimization for all components

\begin{tabular}{l|c|r|c}
\hline \multicolumn{1}{c|}{ Config } & NPC (\$) & $\begin{array}{c}\text { CoE } \\
(\mathbf{\$} / \mathbf{k W h})\end{array}$ & $\begin{array}{c}\text { RF } \\
(\%)\end{array}$ \\
\hline PV/G/Batt & $342,372.80$ & 0.104 & 98,07 \\
\hline PV/WT/G/Batt & $342,947.30$ & 0.104 & 98,13 \\
\hline PV/Batt & $386,179.10$ & 0.117 & 100 \\
\hline PV/WT/Batt & $427,652.30$ & 0.129 & 100 \\
\hline WT/G/Batt & $1,127,107.00$ & 0.341 & 69,86 \\
\hline PV/G & $1,396,037.00$ & 0.422 & 24,13 \\
\hline PV/WT/G & $1,396,921.00$ & 0.422 & 24,19 \\
\hline G/Batt & $1,416,108.00$ & 0.428 & 0 \\
\hline WT/G & $1,524,253.00$ & 0.461 & 0 \\
\hline G & $1,524,350.00$ & 0.461 & 0 \\
\hline
\end{tabular}

Figure 3. Power management for Lagundri microgrid 
The simulation results of the optimal microgrid system configuration for the three locations of microgrid system study area are shown in Table 7 . From these results, only the Mentawai area is feasible to use WT, while the other two locations are not. This is because the average wind speed in the Mentawai location is greater than the other two areas as shown in Table 3. above.

Table 7. Optimal result based on HOMER optimization for the three areas under study

\begin{tabular}{c|c|c|c|c|c}
\hline Location & $\begin{array}{c}\text { PV } \\
(\mathbf{k W})\end{array}$ & $\begin{array}{c}\mathbf{W T} \\
\mathbf{( k W )}\end{array}$ & $\begin{array}{c}\text { Genset } \\
(\mathbf{k W})\end{array}$ & Batt & $\begin{array}{c}\text { Inverter } \\
\mathbf{( k W )}\end{array}$ \\
\hline Lagundri & 169 & & 56 & 416 & 51,3 \\
\hline Mentawai & 164 & 2 & 56 & 416 & 51,0 \\
\hline Mandeh & 146 & & 56 & 420 & 51.3 \\
\hline
\end{tabular}

The economic comparison results of optimal configuration of three proposed microgrid systems are shown in Table 8. The lowest NPC and CoE values were obtained for the case study in Mandeh location with NPC \$316,275.60 and CoE $\$ 0.096 / \mathrm{kWh}$. Likewise, the initial investment costs and operating costs are the lowest among the tested systems. This is because the largest fraction of renewable energy generation occurs in the microgrid system for the Mandeh location, which is $98.76 \%$.

Table 8. The economic comparison results for the three areas under study

\begin{tabular}{l|l|c|c|c}
\hline Location & \multicolumn{1}{|c|}{ Config } & NPC (\$) & $\begin{array}{c}\text { CoE } \\
\text { (\$/kWh) }\end{array}$ & RF (\%) \\
\hline Lagundri & PV/G/B & $342,372.8$ & 0.104 & 98.07 \\
\hline Mentawai & PV/WT/G/B & $338,617.2$ & 0.102 & 98.17 \\
\hline Mandeh & PV/G/B & $316,275.6$ & 0.096 & 98.76 \\
\hline
\end{tabular}

\subsection{Designed Configuration}

Another scenario was designed for the configuration with a fixed PV capacity. This scenario is intended to see the feasibility of installing WT for a microgrid system on the coast of Sumatra. In this study, the PV capacity is set at $100 \mathrm{~kW}$ while the other components are free to follow the Homer optimization system. The simulation results are shown in Table 9., at Mandeh location it is not feasible to build WT. This is due to the low wind speed in Mandeh region. Although Mentawai has a higher average annual wind speed, the lagoon microgrid system can install $86 \mathrm{~kW}$ of wind power because the wind distribution pattern is better than the Mentawai area.
Table 9. Optimal configuration result based on $100 \mathrm{~kW} \mathrm{PV}$ designed

\begin{tabular}{c|c|c|c|c|c}
\hline Location & $\begin{array}{c}\text { PV } \\
(\mathbf{k W})\end{array}$ & $\begin{array}{c}\mathbf{W T} \\
(\mathbf{k W})\end{array}$ & $\begin{array}{c}\mathbf{G} \\
(\mathbf{k W})\end{array}$ & Batt & $\begin{array}{c}\text { Inverter } \\
(\mathbf{k W})\end{array}$ \\
\hline Lagundri & 100 & 86 & 56 & 364 & 48,0 \\
\hline Mentawai & 100 & 67 & 56 & 368 & 47,6 \\
\hline Mandeh & 100 & - & 56 & 404 & 52,3 \\
\hline
\end{tabular}

Based on economic comparison results as shown in Table 10. for three different areas of study. The lowest NPC and CoE values were obtained for the case study in Mandeh location with NPC \$430,434.6 and $\mathrm{CoE} \$ 0.114 / \mathrm{kWh}$. Meanwhile, the lowest operating cost is obtained in the Mentawai microgrid system because it has the largest fraction of renewable energy generation, which is $93.84 \%$. Even though the initial investment cost of Mandeh microgrid system is low, the operational costs are high among the three systems tested. This is due to the small fraction of renewable energy producers. Thus, the configuration of the microgrid generator, the wind speed pattern affects the optimization results of the microgrid system design.

Table 10. Optimal economic result based on $100 \mathrm{~kW} \mathrm{PV}$ designed

\begin{tabular}{l|l|c|c|c}
\hline Location & \multicolumn{1}{|c|}{ Config } & NPC (\$) & $\begin{array}{c}\text { CoE } \\
\mathbf{( \$ / k W h )}\end{array}$ & $\begin{array}{c}\text { RF } \\
\mathbf{( \% )}\end{array}$ \\
\hline Lagundri & PV/G/B & $430,434.6$ & 0.130 & 92.64 \\
\hline Mentawai & PV/WT/G/B & $394,911.3$ & 0.119 & 93.84 \\
\hline Mandeh & $\mathrm{PV} / \mathrm{G} / \mathrm{B}$ & $377,919.6$ & 0.114 & 92.02 \\
\hline
\end{tabular}

\section{Conclusion}

The economic feasibility study of hybrid microgrid power system for three remote islands of Sumatra, Indonesia have been carried out. The simulation results showed that the installation of WT is not feasible for the microgrid area at the Mandeh location because the wind speed is relatively low. But the Mandeh area has a large amount of solar radiation compared to the other two areas, resulting in the lowest CoE of $\$ 0.096 / \mathrm{kWh}$ and low investment and operating costs as well. For the fixed PV $100 \mathrm{~kW}$ scenario, the optimal configuration is obtained with 86 $\mathrm{kW}$ supplied by WT for the Lagundri location, and 67 $\mathrm{kW}$ supplied by WT for the Mentawai area, while the WT installation area is not recommended. From the results of the evaluation of the loading pattern not only average weather parameters affect PV/Wind electrical power production but weather patterns have effect in PV/Wind electrical power production. 


\section{Acknowledgements}

The authors gratefully acknowledge the assistance rendered by Directorate General of Higher Education, Kemdikbudristek for the financial support under PTUPT Research Grant 2021 (Contract No. 266/E4.1/AK.04.PT/2021).

\section{References}

[1]. Sadat, S. A., Faraji, J., Babaei, M., \& Ketabi, A. (2020). Techno-economic comparative study of hybrid microgrids in eight climate zones of Iran. Energy Science \& Engineering, 8(9), 3004-3026.

[2]. Khan, M. A., Aziz, M. S., Khan, A., Zeb, K., Uddin, W., \& Ishfaq, M. (2019, July). An optimized off-gird renewable AC/DC microgrid for remote communities of Pakistan. In 2019 International Conference on Electrical, Communication, and Computer Engineering (ICECCE) (pp. 1-6). IEEE.

[3]. Thomas, A., \& Racherla, P. (2020). Constructing statutory energy goal compliant wind and solar PV infrastructure pathways. Renewable Energy, 161, 119.

[4]. Rajeh, M. A., \& Bensenouci, A., (2019). Design a Hybrid Wind-Solar Power System for Remote Areas of Saudi Arabia. Proceedings of the International Conference on Industrial Engineering and Operations Management Riyadh, Saudi Arabia, November 26-28.

[5]. Chaudhary, V. P., Chandra, R., Chaudhary, R., \& Bhattacharyya, R. (2021). Global warming potential and energy dynamics of conservation tillage practices for different rabi crops in the Indo-Gangetic Plains. Journal of Environmental Management, 296, 113182.

[6]. Hrnčić, B., Pfeifer, A., Jurić, F., Duić, N., Ivanović, V., \& Vušanović, I. (2021). Different investment dynamics in energy transition towards a $100 \%$ renewable energy system. Energy, 237, 121526.

[7]. Islam, M. S., Das, B. K., Das, P., \& Rahaman, M. H. (2021). Techno-economic optimization of a zero emission energy system for a coastal community in Newfoundland, Canada. Energy, 220, 119709.
[8]. Islami, M. S., Urmee, T., \& Kumara, I. N. S. (2021). Developing a framework to increase solar photovoltaic microgrid penetration in the tropical region: A case study in Indonesia. Sustainable Energy Technologies and Assessments, 47, 101311.

[9]. National.Energy.Council, "Indonesia Energy Outlook 2016," (2016). [Online]. Retrieved from: https://www.esdm.go.id/assets/media/content/contentindonesia-energy-outlook-2 \%0A016-versi-inggrismy33nxb.pdf. [accessed: 20 March 2021].

[10]. Putra, I. N., Hakim, A., Pramono, S. H., \& Leksono, A. S. (2017). The effect of strategic environment change toward Indonesia maritime security: Threat and opportunity. International Journal of Applied Engineering Research, 12(16), 6037-6044.

[11]. Winanti, N., Purwadi, A., Halimi, B., \& Heryana, N. (2018, October). Study and Design of Energy-Saving Solar Lamp for Small Island in Indonesia: Matakus Island. In 2018 Conference on Power Engineering and Renewable Energy (ICPERE) (pp. 1-5). IEEE.

[12]. Surjosatyo, A., Dewantoro, B. R., Saragih, B. R., Nainggolan, F., Dwianto, W., \& Darmawan, T. (2018). Selecting and testing of wind turbine blades of the local-wood growing fastly on local wind characteristics. In IOP Conference Series: Earth and Environmental Science (Vol. 105, No. 1, p. 012095). IOP Publishing.

[13]. Nrel, "Homer Powering Health Tool," (2020). Retrieved from:

https://poweringhealth.homerenergy.com/. [accessed: 28 March 2021].

[14]. Okedu, K. E., \& Uhunmwangho, R. (2014). Optimization of renewable energy efficiency using HOMER. International Journal of Renewable Energy Research (IJRER), 4(2), 421-427.

[15]. Olatomiwa, L. (2016). Optimal configuration assessments of hybrid renewable power supply for rural healthcare facilities. Energy Reports, 2, 141-146.

[16]. Kazem, H. A., Al-Badi, H. A., Al Busaidi, A. S., \& Chaichan, M. T. (2017). Optimum design and evaluation of hybrid solar/wind/diesel power system for Masirah Island. Environment, Development and Sustainability, 19(5), 1761-1778. 